\title{
ASSESSMENT OF WOMEN CONCERNS REGARDING EARLY CARE AFTER FIRST LABOR
}

\author{
Prof. Dr. Sanaa Aly Nor, Dr. Seham Shehata Ibrahim,Heba Mohammed Ibrahim. \\ Prof of Obstetric and Gynecology, Faculty of Nursing-Zgazig University, Lecturer of \\ Maternity, Obstetric and Gynecological Nursing, Faculty of Nursing - Port Said \\ University.
}

\begin{abstract}
Objectives: The aim of this study was to Assess of women knowledge and concerns about the early care after labor.

Subject and Methods:. Study was carried out at post-natal department in 3 hospitals in Mansoura City. A cross sectional descriptive exploratory research design was utilized in this study. A simple random sample was used to select the required sample size, The study subjects consisted of $\mathbf{3 0 0}$ women in postpartum department during first 24 hours after labor interview schedule was designed and utilized to collect the necessary data.
\end{abstract}

Results:. The results of this study revealed that $77.7 \%$ of women had physical concern, psychological concern $(69.7 \%)$, concerns related to infant care $(97.3 \%)$, social concerns $(55.0 \%)$, sexual concerns $(18.0 \%)$ and concerns related to family planning $(72.0 \%)$. Every postpartum period is a unique experience for a woman. A significant relation was found between the women concerns and related independent variables among the studied women.

Conclusion: It can be concluded that The current study revealed that a sizable proportion of women had physical concern specifically nutrition, fatigue and perineal pain. The majority of women had also psychological concern about their future role of being a mother and they thought that husbands or family support was imperative during this period and the use of birth control methods was essential as early as they could. In addition, there was a significant relation between various types of concerns and related independent variables .

Recommendations:. the study recommended the development and dissemination of training courses and education programs for the decision makers, workers in health care settings and antenatal clinics to raise awareness of concerns of primipara women and how to address it.

Key words: Postpartum, women concern. 


\section{INTRODUCTION}

It is usually a joyful event when a woman gives birth to a baby she wants. Despite the pain and discomfort, birth is the long-awaited culmination of pregnancy and the start of a new life. However, birth is also a critical time for the health of the mother and her baby. Problems may arise that, if not treated promptly and effectively can lead to illhealth and even death for one or both of them. Nonetheless, the postpartum period is often neglected by maternity care. The lack of postpartum care ignores the fact that the majority of maternal deaths and disabilities occur during the postpartum period and that early neonatal mortality remains high (WHO,2004).

The postpartum period, or peuriperium, starts about an hour after the delivery of the placenta and includes the following six weeks. Postpartum care should respond to the special needs of the mother and baby during this special phase and should include: the prevention and early detection and treatment of complications and disease, and the provision of advice and services on breastfeeding, birth spacing, immunization and maternal nutrition (WHO,2004).

The provision of timely and effective postnatal care and support can have significant impact on the long-term health and wellbeing of women and their families. Postnatal care should be delivered in the woman's home. Irrespective of the postnatal care setting, it is imperative that the care is provided of the highest standard and meets the needs of the individual. Lack of preparation for parenting comprises four factors: lack of previous child care experience, lack of realistic training for parenthood, abruptness of transition and, lack of guidelines to successful parenthood. Some important issues that need to be addressed during the early 24 hours post partum include physical, psychological, social, financial, and sexual and family planning concerns in addition to infant care (Yoo, 2007).

\section{Significance of the Study}

The postpartum period covers a critical transitional time for a woman, her newborn and her family, on a physiological, emotional and social level. Nonetheless, in both developing and developed countries women's needs during this period and those of their newborns have been all too often eclipsed by the attention given to pregnancy and birth. Such an eclipse ignores the fact that the majority of maternal deaths and 
disabilities occur during the postpartum period and that early neonatal mortality remains highr. Therefore, the present study was undertaken to identify concerns of primipara related to early postpartum care. This will consequently help maternity nurses and midwives to recognize new mothers needs, thus provide them with effective postpartum education during early puerperium. Ultimately, this will contribute to maintenance and promotion of women's health status during this important and remarkable period of life.

\section{AIM OF STUDY:}

The aim of this study was to assess of women's concerns about the early care after first labor. Specific Objectives:

This aim was achieved through:

1. Assess women's knowledge and concerns about the early care after labor.

2. Find out the relationship between the presence of these concerns and woman characteristics.

\section{SUBJECT AND METHODS:}

Across-sectional analytic study was carried out at the postpartum inpatient departments after delivery by 24 hours at 3 hospitals representing three district in mansoura city; namely: Elgamalia hospital, Meet salsil hospital and manzala hospital. A simple random sample was used to select the required sample size. The sample consisted of 300 primipara women's were enrolled to this study postpartum primiparous women at age ranged from 18-40 years, delivered vaginally and free from any complication. The instruments used for data collection were an interview questionnaire consisting of two parts. questionnaire consisted of two parts as the following:

Part (1):

Socio demographic data such as: age, age of marriage, marital status, education, occupation, type of family, crowding index, housing condition, income, sex of infant, feeding method and presence of social support as significant others....etc

\section{Part (2):}

Questions related to women s concerns in the early postpartum period these questions covered the following:

- Physical concerns: Such as discomfort, pain, after pain, breast soreness, sleep 
deprivation, lochia, fatigue, weight change and nutrition, constipation, headache and leg pain

- Psychological concerns such as: Postpartum blues, emotional liability, self esteem disturbances, and body image disturbances and adjust maternal role.

- Infant care concerns such as: Methods of feeding, breast-feeding concerns (nipple problems, insufficient milk), care of umbilical cord, immunization schedule, proper temperature regulation, infant bath eye care, diaper change, infant behavior, circumcision to male infant.

- Social concerns such as: Parent behaviors and their reaction, insufficient help with infant care and household tasks, difficulty in organizing daily routines and pressures arising from numerous visitors

- Economic concerns such as: Financial burden arising from newborn responsibilities cost of delivery and ambivalence about returning to work.

- Sexuality concerns such as: Resumption of sexual relation, dyspareunia, change in libido.

- Family planning concerns such as: Timing of use, which method to be used, the advantages and disadvantages of each method ...etc

\section{Content Validity:}

After the tool had been designed, it was tested for its validity and reliability. Then the pilot study was carried out on $10 \%$ of the sample in the study setting that were excluded from the study sample. The purposes of the pilot study were to test the applicability and clarify the feasibility of the study tools and it served to estimate the time needed to complete the tools. It also helped to find out any obstacles and problems that might interfere with data collection, based on findings of the pilot study, certain modification of the tools were done. Subjects included in the pilot study were excluded from the study subjects. Following this pilot study, the process of data collection was performed.

\section{RESULTS}

Table( 1) illustrates The socio-demographic characteristics of women in the study sample the age ranged between 18 and 33 years, with almost three quarters (71.0\%) were below 25 years of age. More than two thirds of them $(71.4 \%)$ were illiterate or could not read and write, and less than one fifth (18.3\%) had secondary education and 
above. The majority were housewives $(77.0 \%)$, with $69.0 \%$ had rural residence, their income just meeting the life expenses' (46.0\%), and the majority helped by their mothers $(89.7 \%)$

Table(2) shows that more than half $(52.0 \%)$ of women thought that after pains are normal, but $67.6 \%$ did not know its causes and almost three fifth $(60.7 \%)$ of women reported that it increases with breast-feeding. Meanwhile, they thought that it can be dealt with by drinking warm fluids or taking analgesics $(33.0 \%$ and $27.4 \%$ respectively).

Table(3) illustrates distribution of primipara according to their postpartum psychological concern. It indicates that (192\%) women were afraid from the responsibility of their future role and the majority (98.3\%) showed the feeling of being worried, and the source of worry was mainly the newborn (48.5\%). However, the vast majority $(98.3 \%)$ of them were satisfied with their body image (98.3\%).

Table(4) shows distribution of primipara according to their postpartum concern about their newborn care. Almost one-third (31.6\%) of women had insufficient or lack of knowledge about the importance of breast-feeding. They thought that it should be started within the first day after delivery (73.6\%), but 32.0\% were unaware about the signs of sufficient breast milk for the newborn. As for the need of newborn to warmth, almost half of them $(56.0 \%)$ reported the right answer, the rest were unaware about this need.

Table (5) shows distribution of primipara according to their postpartum sexual concerns. It was observed that more than two thirds (67.7\%) of women were concerned about the change in sexual desire and $65.7 \%$ thought that it will decrease after delivery. Meanwhile, more than one fourth $(26.3 \%)$ of primipara reported that the cause is due to pain of perineal trauma or the interruption caused by the newborn $(63.3 \%)$

Table (6) represents distribution of primipara according to their concerns about family planning. It was found that more than two thirds (68.4\%) showed concern about using contraceptive method after delivery, however, only few women preferred IUD or chemical contraceptives $(20.0 \%$ and $18.6 \%$ respectively). Also it was observed that $67.3 \%$ of the primipara thought their husband opinion about the chosen method is mandatory.

Table (7) shows the relationship between primiparous postpartum concerns and their age. It was observed that women whose age were more than 20 years were 
significantly more likely to have concern about pain and obstetric concern ( $\mathrm{P} \leq 0.05)$. Moreover, they had more psychological economic, sexual and family planning concerns compared to women with lesser age group and the differences observed are statistically significant $(\mathrm{P} \leq 0.05)$.

Figure (1) shows distribution of primipara according to the total self concerns. It was found that the majority of women had nutritional concern as well as concern about pain after delivery (99.3\% and $98.0 \%$ respectively). Also it was observed that more than three quarters $(77.3 \%)$ had physical concerns, followed by economic and sexual concerns (75.7\% and $67.7 \%$ respectively).

Table (1): Personal Characteristics of the Studied women $(n=300)$

\begin{tabular}{||l|c|c||}
\hline \multirow{2}{*}{ Personal characteristics } & \multicolumn{2}{|c|}{ Studied women } \\
\cline { 2 - 3 } & No. & $\%$ \\
\hline Women's age & 213 & 71.0 \\
Less than 25 & 87 & 29.0 \\
25 and more & 106 & 35.4 \\
\hline Educational level & 108 & 36.0 \\
Illiterate & 31 & 10.3 \\
Read and write & 51 & 17.0 \\
Basic education & 4 & 1.3 \\
Secondary education & 231 & 77.0 \\
University education & 69 & 23.0 \\
\hline Employment & 207 & 69.0 \\
Work & 93 & 31.0 \\
Housewife & 92 & 30.7 \\
Residence & 138 & 46.0 \\
Rural & 70 & 23.3 \\
Urban & 269 & 89.7 \\
\hline Monthly family income & 19 & 6.3 \\
In debt & 11 & 3.7 \\
Just meeting expenses & 1 & 0.3 \\
Able to save & & \\
\hline Person preferred to help the woman & & \\
Mother & & \\
Husband & & \\
Mother in low & & \\
Relatives & & 26.0 \\
\hline
\end{tabular}


Table (2): Distribution of women according to their concern about pain after delivery $(\mathbf{n}=\mathbf{3 0 0})$

\begin{tabular}{|l|c|c|}
\hline \multirow{2}{*}{ Women's Concern about after pain } & \multicolumn{2}{|c|}{$\begin{array}{l}\text { Studied women } \\
\text { (n=300) }\end{array}$} \\
\cline { 2 - 3 } & No. & $\%$ \\
\hline Women's concerns about pains as normal & & \\
Yes & 156 & 52.0 \\
Don't care & 144 & 48.00 \\
\hline Pain causes as expectation by women & & \\
Delivery & 5 & 1.7 \\
Uterine involution & 2 & 0.7 \\
Bleeding & 90 & 30.0 \\
Don't care & 203 & 67.6 \\
\hline The effect of breast feeding on pain & & \\
Increase pain & 182 & 60.7 \\
Decrease pain & 28 & 9.3 \\
Don't care & 90 & 30.0 \\
\hline Dealing with pain after delivery & & \\
Seek medical advice & 19 & 6.3 \\
Analgesics & 82 & 27.4 \\
Use sanitary pads & 4 & 1.3 \\
Sit in warm water & 9 & 3.0 \\
Vaginal wash with antiseptic and warm water & 3 & 1.0 \\
Drink warm fluids & 99 & 33.0 \\
Don't care & & 28.0 \\
\hline
\end{tabular}


Table (3) Distribution of women according to psychological concerns $(n=300)$

\begin{tabular}{||l|c|c||}
\hline \multirow{2}{*}{ Psychological concerns } & \multicolumn{2}{l|}{$\begin{array}{l}\text { Studied women } \\
\text { (n=300) }\end{array}$} \\
\cline { 2 - 3 } & No. & \% \\
\hline Women's feeling of her future role & 192 & 64.0 \\
Afraid from responsibility & 108 & 36.0 \\
Happy and wish to be a good mother & 295 & 98.3 \\
\hline Feel worried & & \\
Yes & 143 & 48.5 \\
\hline Source of being worried [n=295] & 58 & 19.6 \\
Needs of newborn & 19 & 6.4 \\
Needs of husband & 58 & 19.7 \\
House duties & 17 & 5.8 \\
Going back to work & & \\
Family relation & 295 & 98.3 \\
\hline Feeling towards body changes after delivery & 5 & 1.7 \\
\hline Satisfied & & \\
Not satisfied & & \\
\hline
\end{tabular}


Table(4): Distribution of women according to their postpartum concerns about care of new born $(n=300)$

\begin{tabular}{||l|c|c||}
\hline \multirow{2}{*}{ Concerns about care for the newborn } & \multicolumn{2}{|c|}{$\begin{array}{l}\text { Studied women } \\
\text { (n=300) }\end{array}$} \\
\cline { 2 - 3 } Importance of breast feeding & No. & \% \\
\hline Adequate knowledge & 205 & 68.4 \\
Insufficient knowledge & 9 & 3.0 \\
In adequate knowledge & 86 & 28.6 \\
\hline Initiation of breast feeding & & \\
Immediately after delivery & 11 & 3.7 \\
After 3 days of delivery & 2 & 0.7 \\
During 24 hours of delivery & 221 & 73.6 \\
Don't care & 66 & 22.0 \\
\hline Signs of sufficient milk secretion & 193 & 64.3 \\
Calmness of baby, good sleep & 11 & 3.7 \\
Baby growth & 96 & 32.0 \\
Don't care & & \\
Concern about warming the newborn & 248 & 82.7 \\
Yes & 132 & 44.0 \\
\hline Importance of warming the newborn & 4 & 1.3 \\
Protection from common cold and diseases & 10.7 \\
Keep body temperature & & 44.0 \\
Improve growth and development & & \\
Don't care & & \\
\hline
\end{tabular}


Table(5): Distribution of women according to their postpartum sexual concerns. $(\mathbf{n}=\mathbf{3 0 0})$

\begin{tabular}{|c|c|c|}
\hline \multirow[t]{2}{*}{ Sexual concerns } & \multicolumn{2}{|c|}{$\begin{array}{l}\text { Studied women } \\
(\mathbf{n}=300)\end{array}$} \\
\hline & No. & $\%$ \\
\hline $\begin{array}{l}\text { Concern about change of sexual desire after delivery } \\
\text { Yes }\end{array}$ & 203 & 67.7 \\
\hline $\begin{array}{l}\text { Type of desire change } \\
\text { Increase } \\
\text { Decrease } \\
\text { Don't care }\end{array}$ & $\begin{array}{c}10 \\
197 \\
93\end{array}$ & $\begin{array}{c}3.3 \\
65.7 \\
31.0\end{array}$ \\
\hline $\begin{array}{l}\text { Concern about effect of episiotomy on sexual relation } \\
\text { Yes }\end{array}$ & 153 & 51.0 \\
\hline $\begin{array}{l}\text { Type of effect of episiotomy } \\
\text { Pain during intercourse } \\
\text { Decrease desire } \\
\text { Don't care }\end{array}$ & $\begin{array}{c}79 \\
17 \\
204\end{array}$ & $\begin{array}{c}26.3 \\
5.7 \\
68.0\end{array}$ \\
\hline $\begin{array}{l}\text { Concern about effect of newborn on sexual relation } \\
\text { Yes } \\
\text { No } \\
\text { Don't care }\end{array}$ & $\begin{array}{c}190 \\
51 \\
59\end{array}$ & $\begin{array}{l}63.3 \\
17.0 \\
19.7\end{array}$ \\
\hline
\end{tabular}

Table (6): Distribution of women according to their postpartum concerns about family planning $(n=300)$

\begin{tabular}{|l|c|c||}
\hline \multirow{2}{*}{ Concern about family planning } & \multicolumn{2}{|l|}{$\begin{array}{l}\text { Studied women } \\
(\mathbf{n}=300)\end{array}$} \\
\cline { 2 - 3 } & No. & $\%$ \\
\hline Need for using a contraceptive method & 205 & 68.4 \\
Yes & & \\
\hline \#Type of preferred method for contraception & 60 & 20.0 \\
IUD & 7 & 2.3 \\
Pills & 36 & 12.0 \\
Injections & 13 & 4.3 \\
Capsules & 183 & 61.0 \\
Don't care & & \\
& 202 & 67.3 \\
\hline Husband opinion is important in choosing method & & \\
Yes & & \\
\hline
\end{tabular}

\#more than one response. 
Table (7): Relation between postpartum care concerns of the studied women and their age

\begin{tabular}{|c|c|c|c|c|c|c|}
\hline \multirow{3}{*}{\multicolumn{2}{|c|}{ Concerns }} & \multicolumn{4}{|c|}{ Age (years) } & \multirow{3}{*}{ Chi-Square test } \\
\hline & & \multicolumn{2}{|c|}{$\begin{array}{c}\text { Less than } 20 \\
(\mathrm{n}=213)\end{array}$} & \multicolumn{2}{|c|}{$\begin{array}{c}20 \text { or more } \\
(n=87)\end{array}$} & \\
\hline & & No. & $\%$ & No. & $\%$ & \\
\hline \multirow[t]{2}{*}{ Musculoskeletal concerns } & Yes & 159 & 74.6 & 73 & 83.9 & $X^{2}=3.022$ \\
\hline & No & 54 & 25.4 & 14 & 16.1 & $\mathrm{P}=0.082$ \\
\hline \multirow[t]{2}{*}{ Obstetric concerns } & Yes & 201 & 94.4 & 72 & 82.8 & $\mathrm{X}^{2}=10.162$ \\
\hline & No & 12 & 5.6 & 15 & 17.2 & $\mathrm{P}=0.001^{*}$ \\
\hline \multirow[t]{2}{*}{ Pain } & Yes & 165 & 77.5 & 77 & 88.5 & $X^{2}=4.975$ \\
\hline & No & 48 & 22.5 & 10 & 11.5 & $\mathrm{P}=0.083$ \\
\hline \multirow[t]{2}{*}{ Psychological concerns } & Yes & 138 & 64.8 & 71 & 81.6 & $X^{2}=8.27$ \\
\hline & No & 75 & 35.2 & 16 & 18.4 & $\mathrm{P}=0.004^{*}$ \\
\hline \multirow[t]{2}{*}{ Care for the newborn } & Yes & 166 & 77.9 & 82 & 94.3 & $\mathrm{X}^{2}=11.48$ \\
\hline & No & 47 & 22.1 & 5 & 5.7 & $\mathrm{P}=0.001 *$ \\
\hline \multirow[t]{2}{*}{ Economic concerns } & Yes & 148 & 69.5 & 79 & 90.8 & $\mathrm{X}^{2}=15.251$ \\
\hline & No & 65 & 30.5 & 8 & 9.2 & $\mathrm{P}<0.0001 *$ \\
\hline \multirow[t]{2}{*}{ Sexual Concerns } & Yes & 38 & 17.8 & 16 & 18.4 & $\mathrm{X}^{2}=0.013$ \\
\hline & No & 175 & 82.2 & 71 & 81.6 & $\mathrm{P}=0.91$ \\
\hline \multirow[t]{2}{*}{ Family planning } & Yes & 144 & 67.6 & 72 & 82.8 & $\mathrm{X}^{2}=7.035$ \\
\hline & No & 69 & 32.4 & 15 & 17.2 & $\mathrm{P}=0.008^{*}$ \\
\hline
\end{tabular}

*significant at $P \leq 0.05$

Figure (1): Distribution of Self Concerns among the Studied Women

\section{Distribution of Self Concerns among the Studied Women}

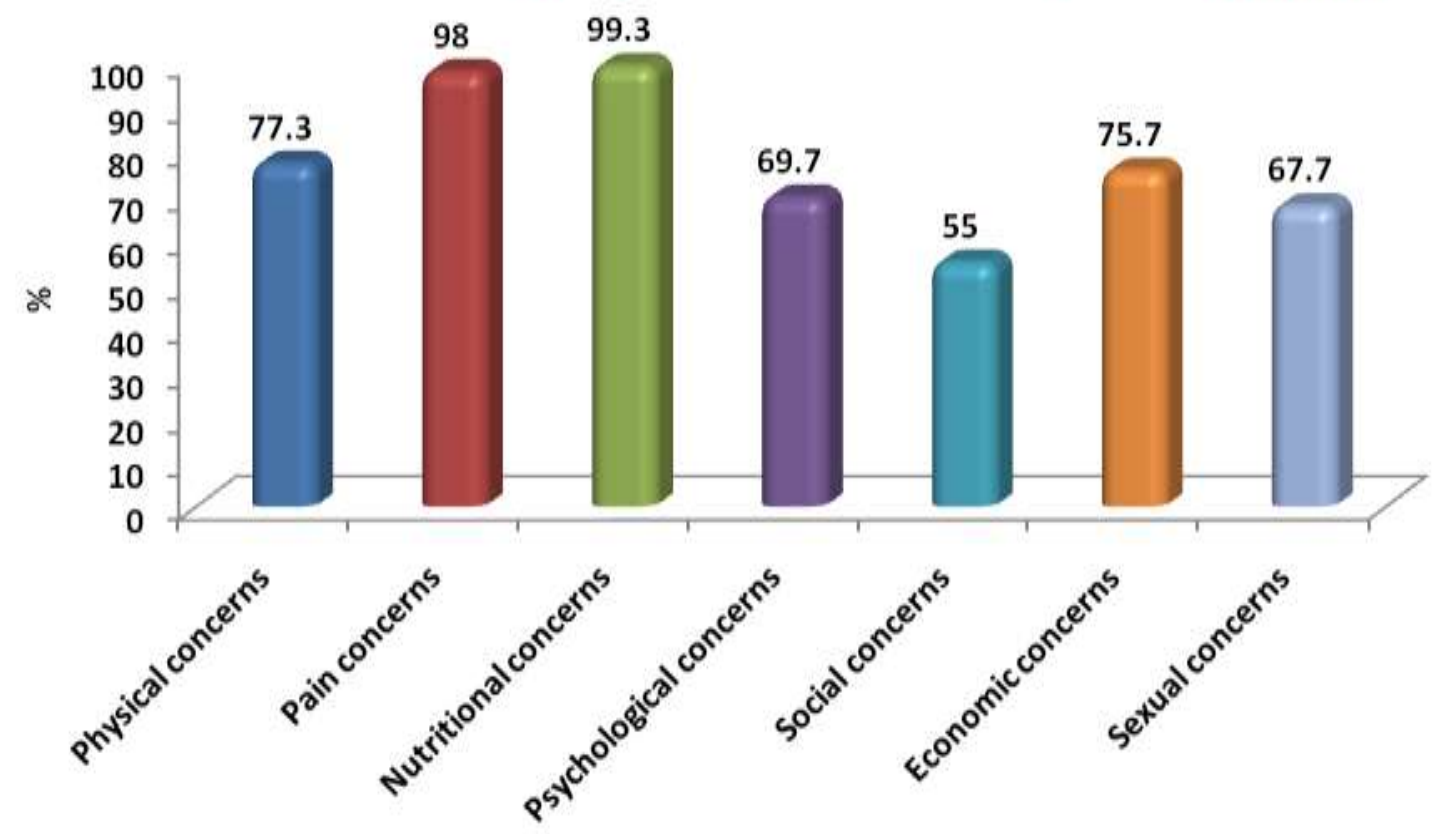




\section{DISCUSSION}

The postpartum period is a critical stage for both the mother and baby. Both are recovering from the physical process of birth, and they are also initiating a new relationship. In the first hours and days following childbirth, the mother undergoes dramatic physiologic adaptations involving nearly every system of her body. Generally, postpartum women experience relatively little discomfort and are most concerned with rest, relieving perineal discomfort, and learning about their newborn. Nevertheless, the postpartum period is a time of physical adjustment, healing, emotional mood swings, and expanding roles (Collins, 2007). However, women perceive childbirth as a major event but may view the postnatal period with less concern (Warren et al., 2005).

Throughout the postpartum period, the plan of care is continually altered to meet the educational needs of the mother, based on their concerns (Collins, 2007). The job of the postpartum nurse is to help the new mother regain her pre-pregnant state without complications and to provide a solid knowledge base of care for the new mother and her infant. The desired outcome is that the mother feels confident about taking care of herself and her infant and be prepared to resume her normal role in the community. Therefore, the present study was conducted to assess women knowledge and concerns about the early care after labor.

After pains related concerns were noted among the majority of primipara in the present study and about one-half of them thought they are normal and mostly due to labor and increased with breast-feeding. This finding is matching with Derricott (2010) who emphasized that after pains are normal intermittent uterine contractions that occur during the first few days after delivery due to the release of the oxytocin and they increased as result of nipple stimulation, which stimulates the posterior pituitary gland to excrete oxytocin and in turn aggravates after pains.

On investigating the methods used by women for coping with after pains they include; taking analgesics on their own and drinking warm fluids. Some of them thought of taking rest and avoiding breast-feeding. It is well known that taking medication without doctor is not allowed as mentioned before. Also, avoiding breast-feeding may lead to breast engorgement, using formula feeding for the babies and inhibit bonding 
between them, coping strategies necessitate relaxation techniques and if necessary, analgesics Derricott (2010). Unlike, Weiss (2011) who suggested that most mothers do not require pain medication for these pains.

It was also expected to find that a sizable proportion of primipara had concern about backache, because the lower back muscles are used, along with the pelvic muscles, during vaginal birth. Sometimes this pushing can strain the muscles or ligaments in the lumbar region of the back causing backache. Backache may also occur due to coccyx pain during a vaginal birth; when the coccyx is flexible and is supposed to move out of the way of the birth passage (Rostock et al., 2006). In congruence with the foregoing current study findings, the survey of Ansara et al. (2005) in Canada also revealed that, it was the most common health problem (43.5\%) and that at 2 months postpartum, more than one-half of mothers $(54.5 \%)$ experienced pain in the back.

Concern about perineal discomfort was noted among the majority of primipara which was mainly ascribed to episiotomy and its suture. Similarly, Brown \& Lumley (1998) survey in Australia reported that perineal pain is one of the most common health problems (21\%), while Ansara et al. (2005) revealed that at 2 months postpartum, many mothers experienced pain in the perineum (45.9\%). Moreover, Macarthur (2004) found that $92.0 \%$ of Canadian women complained of significant perineal pain on the day after vaginal delivery. This percentage dropped to $61.0 \%$ and $7.0 \%$ seven days and six weeks after childbirth, respectively depending on the degree of trauma or tearing of the perineum or the use of episiotomy. Also, Bowman (2005) concluded that stitches and episiotomy were the most important maternal care learning needs during the first 3 postpartum days.

Concerning the coping mechanisms, it was noticed that few of them consulted their physician while, a great number took oral analgesics on their own, sat in warm water with antiseptic solution. These wrong practices may stem from women's lack of education about perineal hygiene, shame from being exposed again to the doctor or simply lack of time as new mothers to treat themselves. Conversely, Corkill et al. (2001) study in England found that lignocaine gel was effective in relieving perineal pain on the second postnatal day, In addition, Minassian \& Jazayeri (2002) randomized controlled trial in Texas to assess the efficacy of 5\% lidocaine ointment compared with placebo, found that $5 \%$ lidocaine was not effective in relieving pain 
experienced following an episiotomy or perineal laceration. Also, in accordance with the present result Demott et al. (2006) found that non-drug perineal pain relieving therapies, such as sitz baths, ice packs, and wash bottles, were used by most women on the first day after childbirth, till the day seven after birth to relief perineal pain.

It was surprising to find in the present result that more than one-third of primipara thought that dieting is the best method to control increased body weight during postpartum period. This concern is completely wrong as body weight is decreased as mentioned before. It was also wrongly reported that a sensible diet are the best way to lose weight slowly after pregnancy and birth (Victorian Department of Health 2010).

It was surprising to find in the present study that three-fifth of primipara had psychological concerns; this may be due to the fact that they are worker women, had enough income and thus the psychological needs take the highest priority and should be satisfied first. In agreement with this, Cheng \& Chen (2011) in China showed that psychological concerns were increased from the early postpartum period to one-month postpartum, and in primipara they were increased more significantly.

It was expected to find in the present result that women who had psychological concern were exposed to fear, suspicion and anxiety toward the new maternal role. This may be attributed to their ignorance about baby-care skills, or feeling of loss of control in their lives and lack of time and space for themselves. This interpretation is partially similar to Leahy-Warren (2007) study in Ireland who noticed that a woman's transition to motherhood, although a joyous occasion in most instances, it could be a distressing time, particularly because first-time mothers are faced with the demands of learning new skills relating to infant care practices. In this regard, Cheng \& Chen (2001) suggested that postpartum health education should provide more information and technical practice focusing on maternal role.

Anxiety and uncertainty or dissatisfaction about body image were reported by a sizable proportion of the primipara, mostly because of newborn's needs, husband's needs, increased household activities or the actual change in body image. This is incoherence with Fishbein \& Burggraf (2000); Aston (2002) who stated that child-care 
responsibilities and lack of knowledge and preparation or body changes are sources of frustration and anxiety for new mothers.

Furthermore, and in line with the preference of breast-feeding for the new mothers Sword \& Watt (2005); Ricci (2007) mentioned that first-time breast-feeding mothers often have many questions and concerns about newborn feeding regardless of their socioeconomic status. Although some of the primipara recognized the benefit of breast feeding for the baby most of them didn't have concern about its benefits for themselves and were unaware about the proper time of initiation of breast feeding. Controversially, Mohrbacher \& Stock (2006) emphasized the significant value of breast-feeding to infants, mothers, families and the environment especially during the first six months. Meanwhile, Wikipedia (2011) mentioned that the ideal time to start breast-feeding is in the first half hour after birth because the baby's suckling reflex is strongest, and the baby is more alert. Early breast-feeding is also associated with fewer night-time feeding problems. It also reduces the risk of hypothermia and hypoglycemia as the baby being close to the mother (Neonatal division AIIM, 2011).

The study finding revealed that three-fifths of primipara thought that signs of sufficient amount of breast milk for the baby are good sleep, refusal of the breast and less crying. Unlikely Iwinski (2006) stated that while it can be hard to measure how much food a breastfed baby consumes, babies normally feed to meet their own requirements. Babies that fail to eat enough may exhibit symptoms of failure to thrive. Also, most of the primipara was concerned about their infant care; this possibly because they are new mothers and don't have experience in this issue. Thus, it is recommended that new mothers should have constant information about baby's general health, behavior, and care (Lugina et al., 2001).

Most of the studied subjects had concern about baby warmth, to avoid respiratory tract infection, this is right because warmth is one of the basic needs of the newborn and it is critical for baby's survival and wellbeing (AIIM, 2011). They also thought that cord care is important to prevent its contamination and speed it healing and used alcohol for its cleaning. This was disagreed with AL-Taher et al. (2010) who suggested that baby's stump can be washed with plain water, or with a mild, un-perfumed soap or a 
little PH neutral baby cleanser, gently patted with a soft towel or cloth and left to dry properly. The Cochrane review of Zuspan \& Garner (2000) revealed that cords allowed to dry naturally separates earlier than cords treated with alcohol. They reported that alcohol causes destruction of normal flora and lead to longer separation time. In addition, the evidence-based study of Shuaib \& Abu EL-Fadle (2005) supported discontinuation of alcohol use and using the natural drying method for newborn's cord care.

The present study has also demonstrated that most of women recognize the need for male circumcision, but more than one-quarter of them thought that it should be within the first four weeks. However, Dileo (2010) recommends that male circumcision is best done after 24 hours of life, so that the pediatrician has had a chance to check the baby. Waiting any longer allows the baby to further develop the sheathing over his nerves that will better carry pain sensation.

The current finding concerning sexual concern was in line with Dixon et al. (2000); La Marre et al. (2003) who attributed this to the lack of professional recognition about the importance of sexuality to women reproductive life and that health care providers usually focus on the infant's adjustment and mother's physical needs. Sexual functioning may decline due to, episiotomy or low levels of estrogen in breast-feeding postpartum women which is associated with a decrease in vaginal lubrication and genital vaso-congestion, as well as atrophy of the vaginal epithelium which may lead to dysparunia. The prolonged loss of sexual desire may be associated with postnatal depression and decrease of sexual desire and dysparunia which may have impact on women's health. One-quarter of women thought that sexual relation should be started after one or two months.

Similarly, Huan Ying (2003) reported that sexual intercourse was resumed by two months of giving birth by $52 \%$ of Chinese women. While, it was resumed within six weeks among $57 \%$ of American and British women, Connolly (2005) as well as among $42 \%$ of Turkish women Geckil (2009). Also, a sizable proportion of the studied subjects had concern about the use of contraceptive methods especially IUD and CPs and this is encouraging since early postpartum period is an appropriate time for a woman to consider her contraceptive needs, to maintain the health of the mothers 
and children as well as to improve the socioeconomic status of the family. It decreases maternal mortality and morbidity; helps empower women to improve their quality of life; this in turn improves their health status and provides them with increased opportunities for participation in educational, economic and social activities. Samuel (2001) in Uganda revealed that the major advantages cited for using family planning included economic reasons (28\%), spacing of children $(25.7 \%)$ and health reasons $(6 \%)$.

Moreover, Egypt Demographic and Health Survey (2005) reported that $37 \%$ of currently married women are using the IUD, $10 \%$ are relying on the pills, and $7 \%$ are employing injectables, Also, he Cochrane database systematic review of Grimes et al. (2003) reported that although IUDs may be inserted immediately after delivery, the usual practice is to wait until six weeks postpartum because of an increased risk of expulsion. In addition, The American College of Obstetricians and Gynecologists (2000) suggested that progestin-only contraceptives (Depo-Provera and pills) are the best hormonal contraceptive choice for breast-feeding women. However, Demott et al. (2006) mentioned that contraception is needed from three weeks postpartum and condoms are safe until the chosen method can be started. They added that women require adequate information, support and advice to make informed decisions about methods and timing of birth control.

From the results of this study, it is evident that there was statistically significant relation between primiparous postpartum concerns and their age. It was observed that women whose age were more than 20 years were significantly more likely to have physical concern compared to women with younger age group this is due to experience and increase awareness of women by increase age. The postpartum period is a very special phase in the life of a woman and her newborn. For women experiencing childbirth for the first time postnatal period is marked by strong emotions, dramatic physical changes, new and altered relationships and the assumption of and adjustment to new roles. It is a time of profound transition, making great demands on the woman's resilience and capacity to adapt. For a young girl, this period marks a sometimes bewildering acceleration of the normal transition to a new identity as a women and as a mother. The postpartum period is a social as well as a personal event and has meaning well beyond the simple physiological events which mark it. For 
the most part it holds no great dramas and is a reason for celebration and a sense of achievement, although for some the loss of a child or its birth with severe abnormality brings grief and pain. (WHO, 2004).

\section{CONCLUSION:}

Based on study findings, it can be concluded that:

It can be concluded that: The current study revealed that a sizable proportion of women had physical concern specifically nutrition, fatigue and perineal pain. The majority of women had also psychological concern about their future role of being a mother and they thought that husbands or family support was imperative during this period and the use of birth control methods was essential as early as they could. In addition, there was a significant relation between various types of concerns and related independent variables.

\section{RECOMMENDATIONS:}

Based on the results of the present study, the following recommendations were suggested It is recommended that Maternity nurses should counsel puerperal women about the various types of concern, and help them to cope with the difficulties encountered. Further research is proposed to assess the effect of nursing interventions in helping women to cope with these concerns, research duplication of the study on a large sample that includes both primipara and multipara with normal and caesarian birth and take all postpartum period.

\section{REFERENCES:}

Al-Taher H., Ambler R., Brown H. and Fox A. Caring for your baby's umbilical stump. 2010. Available at URL: http://www.newborn who cc. Org/nnf.htm\# New Delhi. Last accessed on: 9 December 2011.

American College of Obstetricians and Gynecologists. Breast-feeding: Maternal and infant aspects. ACOG 2007; 12(1): 1-16.

Ansara D., Cohen M., Gallop R., Kung R. and Schei B. Predictors of women's physical health problems after childbirth. Journal of Psychosomatic Obstetrics and Gynecology 2005; 26: 115 -25. 
Aston M. Learning to be a normal mother: Empowerment and pedagogy in postnatal classes. Public Health Nursing 2002; 19: 284-93.

Bowman K. Postpartum learning needs. J Obstet Gynecol Neonatal Nurse. 2005 JulAug; 34(4): 438-43.

Brown S. and Lumley J. Maternal health after childbirth: result of an Australian population based survey. An International Journal of Obstetrics and Gynecology 1998; 105(2): $156-61$.

Cheng CH., Fowles E. and Walker L. Postpartum maternal health care in the United States: A critical review. J Perinat Educ. 2006 Summer; 15 (3): 34-42.

Collins $N$. Normal postpartum care: continuing education course for health care professionals. 2007; 10-18.

Corkill A., Lavender T., Walkinshaw S. and Alfirevic Z. Reducing postnatal pain from per meal tears by using llgnoealne geli a double-blind randomized trial. Women's Health Nursing Journal 2001 March; 28(1): 22-7.

Derricott B. Postpartum care. 2010. Available at URL: http:// www.nursingceu.com/courses/309/index_nceu.html last accessed on: 14 February 2011.

Dileo G. Common postpartum concerns. 2010. Available at URL: http://www.ncbi.nlm.nih.gov/pubmed/17944781. Last accessed on: 12 July, 2007.

Dixon B. and Powell R. Sex and relationships following childbirth: A first report from general practice of 131 couples. British Journal Practice 2000; 50 (452): 223-4.

Egypt Demographic and Health Survey. Calverton, MaryLand: Ministry of Health and population, National Population Council and ORC Macro, March 2006; 65-90

Fishbein E. and Burggraf E. Early postpartum discharge: How are mothers managing? Journal of Obstetric, Gynecologic, \& Neonatal Nursing2000; 27 (2):142-8. 
Fort A., Kothari M. and Abderrahim N. Postpartum Care: Levels and Determinants in Developing Countries (Comparative Report 15). 2007. Available at URL:http://www.measuredhs.com /pubs/pub_details. cfm ?ID=676. Last accessed on: 2 August 2007

Geckil E., Sahin T. and Ege E. Traditional postpartum practices of women and infants and the factors influencing such practices in South Eastern Turkey. Midwifery 2009; 25 (1): 62-71

Hamza S. The maternal mortality: Egyptian national maternal mortality study. ASJOG 2005 March; 306(2): 306-7.

Huan-Ying W., Yang X., Yao Z. and Zhou Q. Impact of delivery types on women's postpartum sexual health. Reproduction \& Contraception 2003; 14(4):237-42.

Iwinski S. Is weighing baby to measure milk intake a good idea? Leven 2006; 42(3): 51-3.

LaMarre K., Paterson Q. and Gorzalka B. Breast-feeding and postpartum maternal sexual functioning: a review. The Canadian Journal of Human Sexuality. Fall-Winter 2003.

Leahy-Warren P. Social support for first-time mothers: An Irish study. The American Journal of Maternal/Child Nursing 2007 November/December; 32(6): 368-74.

Lugina H., Christensson K., Massawe S., Nystrom L. and Lindmark G. Change in maternal concerns during the 6 weeks postpartum period: a study of primaparous mothers in Dares Salaam, Tanzania. J Midwifery Women's Health. 2011 Jul- Aug; 46 (4): $248-57$.

Macarthur A. Pain after childbirth common, often untreated. American Journal of Obstetrics and Gynecology 2004 November; 191:1199-204. 
Minassian $\boldsymbol{V}$. and Jazayeri $\boldsymbol{A}$. Randomized trial of lidocaine ointment versus placebo for the treatment of postpartum perineal pain. Obstetrics and Gynecology 2002; 100(6 ):1239- 43 .

Mohrbacher N. and Stock $J$. The womanly art of breastfeeding. $7^{\text {th }}$ ed. New Zealand: La Leche League International, 2006; 340-50.

Neonatal Division, AIIMS, New Delhi. Module 1: Care of the baby at birth (During one hour after birth). Available at URL: http://www.Newborn whocc.org/enn/Care_at_Birth1.pdf last accessed on: 9December 2011.

Ricci S. Essentials of maternity, newborn, and women's health nursing. $9^{\text {th }}$ ed. Philadelphia: Lippincott Williams and Wilkins, 2007; 414.

Rostock S., Davis E., Gietzen R., Shoshny S., Mills A., Yass M. and Cohen M. Postpartum back pain. 2006. Available at URL: http://www.cure-back-pain.org/. last accessed on: 16 September 2011.

Samuel $\mathbf{K}$. Obstacles to male participation in family planning: a study in kiyeyi-tororo $\begin{array}{llll}\text { district. } & \text { 2001. Available URL: }\end{array}$ http:www.chdc.mak.ac.ug/publications/kabwigu\%20Samuel\%202001\%20Obstacles\%20 to\%20Male\%Participation\%20in\%20Family\%20Planning.pdf. Last accessed on: 9 December 2011.

Shuaib F. and Abu Al-Fadle S. alcohol or traditional methods versus natural drying for newborn's cord care. JEHA 2005; 80(1-2):196.

Sword W. and Watt S. learning needs of postpartum women: Does socioeconomic status matter? Birth 2005; 32 (2): 86-92.

Victorian Department of Health. Postnatal Exercise. Available at articles.nsf/pages/ postnatal exercise? Open. Last accessed on: 24 November 2011.

Walker L., Sterling B., Kim M., Arheart K. and Timmerman G. Trajectory of weight changes in the first six weeks postpartum. JOGNN 2006; 35: 472-81. 
Weiss R. Postpartum pain relief. Available at Last accessed on: 10 June 2011 URL:http://pregnancy.about.com/od/postpatumrecover/a/postpartumpain.htm.

Wikipedia, The Free Encyclopedia Breast-feeding. Available at URL: http://en.wikipedia.org/wiki/Breastfeeding. Last accessed on 9 December 2011.

World Health Organization (WHO). Mother-baby package: implementing safe motherhood incountries. WHO, Geneva 1994d (WHO/FHE/MSM/94.11).

World Health Organization (WHO). World Health Day -Safe Motherhood. Geneva: WHO. 2004

Yoo $\mathbf{J}$. A study on the home health care needs of postpartum women . Korean $\mathbf{J}$ Women Health Nurse. 2007: 7(4): 579-595. Available at http:// www.Koreamed-basic search.html.

Zuspan J. and Garner P. Topical umbilical cord care at birth (Cochrane Review). Oxford: The Cochrane Library, 2000; 3: Update Software. 


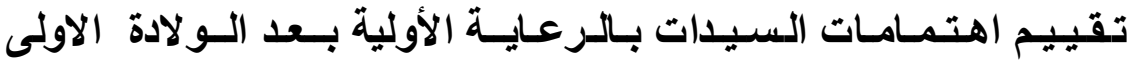

\author{
أ.د / سناءعلي نور- د/ سهام شحاته ابراهيم- م/ هبه محمد ابراهيم عبده مصطفى \\ أستاذ تمريض النساء و التوليد ـ كلية التمريض ـ جامعة الزقازيق ـ مدرس تمريض الأمومة و النساءو و التوليد - \\ كلية التمريض - جامعة بورسعيد - مدرسه بمدرسة التمريض - بميت سلسيل- دقهليه \\ الـخـلاصـــة مدرنة
}

الانتقال لمرحلة الأمومة موقف صعب في الحياة لكنها ليست محنة، ولهذا فعلى مقدمي الرعاية الصحية أن يسهلوا على الأم الاتتقال لهذه المرحلة، ولهذا لابد أن يكونوا مدركين للاهتمامات المختلفة لفترة النفاس. وتهدف هذه الدراسة إلى تقييم اهتمامات السيدات بالر عاية الاوليه بعد الولادة الأولى، أجريت هذه الدر اسة في قسم ما بعد الولادة في ثلاث مستشفيات عامه في مدينة المنصورة علي 300 سيده خلال الأربع و العشرون ساعة الأولى بعد الو لادة، وقد جمعت تللك المعلومات عن طريق استمارة استبيان المقابلة الثخصية، وقد أظهرت نتائج الدراسة أن هناك حو الي (77.7\%) من النساء لديهن اهتمامات جسديه،وان (69.7\%) لايهن اهتمامات نفسيه، وان (97.3\%) لديهن اهتمامات بالعناية بالمولود، وان (55\%) لديهن اهتمامات اجتماعيه، وان (18\%) لايهن اهتمامات جنسيه، وان (72\%) للايهن اهتمامات بتنظيم الأسرة ،وقد تلخصت الدر اسة فيما يلي أن عدد كبير من النساء لديهن اهتمامات جسديه وخاصة التغذية ،الإرهاق الجسدي وآلام العجان ،أيضا لديهن اهتمامات اقتصاديه نتيجة لاحتياجات المولود و هذا سبب رجوعهن للعمل ،معظم النساء لديهن اهتمامات نفسيه تجاه دورهن المستقبلي ،ووجد أن استخدام وسائل تنظيم الأسرة مهم جدا. ولذلك أوصيت الدراسة بتطوير ونشر الدورات التدريبية وبر امج التوعية والتثقف لكل من صناع القرار و العاملين بالصحة وعيادات متابعه الحمل للتوعية باهتمامات السيدات بعد الولادة الأولى وكيفية تلبية هذه الا هتمامات . 